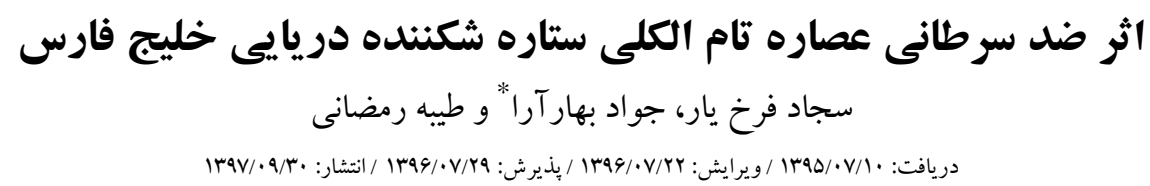

مر كز تحقيقات بيولوزى كاربردى تكوين جانورى، دانشگاه آزاد اسلامى واحد مشهد، مشهد، ايران baharara@mshdiau.ac.ir مسئول مكاتبات

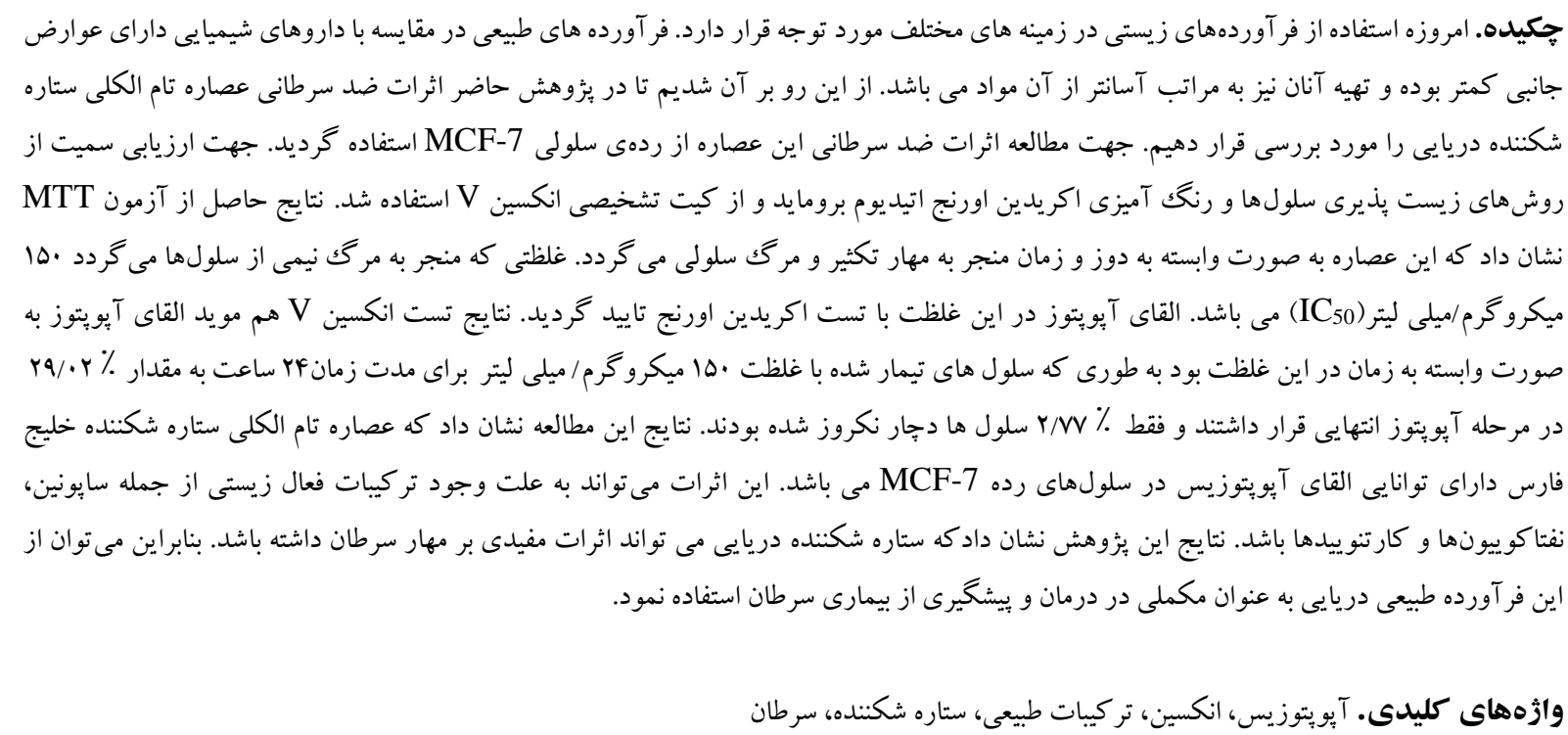

\title{
Anti-cancer effects of the methanolic extract of Persian Gulf brittle star
}

Sajad Farrokhyar, Javad Baharara* \& Tayebeh Ramezani

Received: 01.10.2016 / Revised: 14.10.2017 / Accepted: 21.10.2017 / Published: 21.12.2018

\begin{abstract}
Research Center for Animal Development Applied Biology, Islamic Azad University of Mashhad, Mashhad, Iran *Correspondent author: baharara@mshdiau.ac.ir
\end{abstract}

\begin{abstract}
Nowadays natural compounds are increasingly used in various fields since they cause fewer adverse side effects than their chemical counterparts. In addition, preparation and production of natural compounds are comparatively simple. The present study aimed to evaluate the anti-cancer effects of brittle star methanol extract on MCF-7 cells. Anti-cancer effects of brittle star methanol extract were examined on the MCF-7 cell line. Moreover, the toxicity of this compound was assessed using cell apoptosis methods, ethidium bromide/acridine orange (EB/AO) staining and Annexin $V$ Apoptosis Detection Kit. According to the MTT assay, the methanolic extract of brittle star could prevent proliferation in a time- and dose-dependent manner. The calculated inhibitory concentration that decreased the cell-viability by half $\left(\mathrm{IC}_{50}\right)$ was estimated at $150 \mu \mathrm{g} / \mathrm{ml}$. On the other hand, results of EB/AO staining were indicative of increased apoptotic cells in the treatment group. In addition, results of Annexin V/PI protocol demonstrated a significant enhancement in the percentage of late apoptotic cells $(29.02 \%)$ in the treatment groups $(150 \mu \mathrm{g} / \mathrm{ml})$ and the percentage of necrotic cells were $2.77 \%$ for a period of 24 hours. According to the results, the methanolic extract of Persian Gulf brittle star induced apoptosis in the MCF-7 cell line. These effects could be attributed to the presence of certain active biological compounds, such as Saponins, Naphthoquinones and Carotenoids. Furthermore, our findings suggested that brittle star might have beneficial effects on cancer management. Therefore, this natural marine compound could be used as a complementary element in the prevention and treatment of cancer.
\end{abstract}

Keywords. annexin V, apoptosis, brittle star, cancer, natural compounds 


\section{INTRODUCTION}

As one of the most prevalent diseases among women, breast cancer is associated with a high rate of mortality in Iran. This disease is a substantial concern considering its individual and social damages. In international studies, breast cancer has been reported to have the highest mortality rate among gynecologic cancers, constituting over $25.5 \%$ of all the cancer cases among women (Mousavi et al., 2007)

Global incidence rate of breast cancer has been estimated at 1,385,155 cases per year (Roohparvarzade et al., 2014). Analysis of breast cancer cases across the world shows an alarming trend, and it is predicted that the prevalence of this disease would increase by $26 \%$, particularly in developing countries (Entezar, 2012). Epidemiological trend of breast cancer in Iran is relatively similar to countries in the Eastern Mediterranean Region and other developing countries.

A noticeable change in the incidence rate of breast cancer has been reported in recent years. According to the statistics provided by the Disease Management Centre of the Ministry of Health, breast cancer remains the leading gynecologic cancer type in terms of the incidence rate. In 2007 breast cancer was reported to have the highest incidence in Iran, with the age-standardized rate (ASR) of $27.15(6,976$ cases) (Entezar, 2012).

Various factors have been reported to be involved in the incidence of breast cancer in Iran, including the increased consumption of tobacco and its related products, growing prevalence of overweight and obesity, unhealthy lifestyle and dietary habits, lack of physical activity, inadequate consumption of micronutrients in certain demographic groups in various climates, diversity and complexity of influential environmental factors (e.g., air pollution in megacities), employment-related issues and industrialization. Therefore, lifestyle adjustment would be a proper measure for the prevention of breast cancer (Rooh parvarzade et al., 2014).

Natural marine products have been used increasingly owing to their strong medicinal potential in the treatment of various inflammatory diseases (Amini et al., 2017). In traditional medicine, marine organisms have been used to manage wounds and their complications (Saunders \& Wallace, 2010). Biological diversity of marine ecosystems has resulted in the extraction of numerous active biological materials, which have been applied in various studies and in the To prepare methanol extract, $250 \mathrm{cc}$ of methanol was added to 25 grams of powdered brittle star $(10 \mathrm{cc}$ methanol per one gram of powdered brittle star) and development of modern medicines (Leelaprakash \& Dass, 2011). Ophiuroidea (brittle star) is a class of echinoderms that are known for their ability to regenerate their arms (Carnevali, 2006). Brittle star is rich in several active biological compounds, such as Naphthoquine, Carotenoid sulfate and Steroid glycosides (Govindappa et al., 2011).

Apoptosis is the programmed physiological cell death, which plays a pivotal role in tissue homeostasis. In the initial phases of apoptosis, the cell membrane undergoes certain changes including the transfer of phosphatidylserine (PS) from the internal layer of the membrane to its external layer. Annexin- $\mathrm{V}$ is a cellular calcium-dependent protein that binds to phospholipids with a high propensity toward PS, which makes it a suitable and sensitive marker for the detection of PS on the cell surface. It is notable that PS transfer is not exclusive to apoptosis as it also takes place in necrosis. These two types of cell death could be differentiated. While in the initial phases of apoptosis the cell membrane is intact, in necrosis the cell membrane immediately loses its integrity. Therefore, the use of natural compounds such as propidium iodide is essential to the detection of membrane damage as well as the distinction between necrosis and apoptosis.

With this background in mind, the present study aimed to evaluate the anti-cancer effects of the methanolic extract of Persian Gulf brittle star on the MCf-7 cell line.

\section{MATERIALS AND METHODS}

This experimental laboratory study was conducted at the Research Center for Animal Development Applied Biology, Mashhad Branch, Islamic Azad University, Mashhad, Iran.

\section{Sample collection and preparation}

Live samples of Persian Gulf brittle stars were collected in the early spring (2013) from the coast of Qeshm Island (depth: 3-4 meters). After being washed and cleaned, collected samples were frozen for 24 hours at the temperature of $-20^{\circ} \mathrm{C}$ and transferred to the Research Center for Animal Development at the Islamic Azad University of Mashhad. After being identified and classified by morphometric methods, the samples were placed in a freezer with the temperature of $-80^{\circ} \mathrm{C}$.

\section{Preparation method of brittle star methanol extract}

mixed in the dark for 72 hours. Then the mixture was filtered and condensed by means of a rotary evaporator. The obtained combination was moved to 
a plate covered with aluminum foil and kept in an incubator at the temperature of $40^{\circ} \mathrm{C}$ until full evaporation. Finally, the extract was refrigerated after it was dried. It is noteworthy that, the temperature was never above $40^{\circ} \mathrm{C}$ throughout the extraction process so that the proteins and other active elements would be protected.

\section{Evaluating anti-cancer properties of cell culture}

Human breast cancer cell lines (MCF-7) were cultured in RPMI 1640 medium supplemented with $10 \%$ fetal bovine serum, 100 units $/ \mathrm{mL}$ penicillin, and $100 \mu \mathrm{g} / \mathrm{mL}$ streptomycin, incubated at $37^{\circ} \mathrm{C}$ under a $5 \% \mathrm{CO}_{2} / 95 \%$ air atmosphere.

\section{Cytotoxicity assay}

In the 3-(4,5-dimethylthiazol-2-yl)-2,5-diphenyl tetrazolium bromide (MTT) assay, $5 \times 10^{4}$ cells were placed in each well of a 96-well culture plate, and the brittle star methanol extract was added with the concentrations of 200,150,100, 50 and $25 \mu \mathrm{g} / \mathrm{ml}$; each of the concentrations occupied three wells. After 24 and 48 hours, 20 microliters of the MTT compound was added to each well in the dark. After 3-4 hours of incubation at the temperature of $37^{\circ} \mathrm{C}$, purple formazan crystals were formed inside the cells. In the following stage, 100 microliters of DMSO was added to each well. Finally, the plate was inspected by means of a spectrophotometer (Biotek, USA), and light absorption was measured at the wavelength of $570 \mathrm{~nm}$. Percentage of the living cells was calculated using the following formula (Stoddart, 2011):

Percentage of living cells $=$ Mean absorption of treated samples/Mean absorption of control samples * 100

\section{Cell Death (Apoptosis) Measurement}

\section{Annexin-V/Propidium Iodide (PI)}

In order to measure apoptosis, the cells were kept with $150 \mu \mathrm{l} / \mathrm{ml}$ of the brittle star methanol extract for 24 hours. Then the cells were harvested and collected by centrifugation and resuspended in $500 \mu$ l of binding buffer from the content $\mathrm{s}$ of the kit. Moreover, $5 \mu \mathrm{l}$ of Annexin-V and $5 \mu \mathrm{l}$ of PI were added to the cell solution, which was preserved in the dark for five minutes. Finally, the cells were analyzed by flow cytometry.

\section{Acridine Orange/Ethidium Bromide (AO/EB) staining}

For acridine orange and ethidium bromide staining, MCF-7 cells were treated with $150 \mu \mathrm{l} / \mathrm{ml}$ of brittle star methanol extract for 24 hours. Then the cells were harvested and collected by centrifugation. In the following stage, $5 \mu \mathrm{l}$ of acridine Orange and $5 \mu \mathrm{l}$ of ethidium bromide were added to the cell solution, which was preserved in the dark for 2-3 minutes. The obtained compound was placed on a coverslip and observed by means of a fluorescence microscope (With magnification of 40X), equipped with a special filter (510-590 nanometers). Finally, the percentage of the cells affected by apoptosis was determined using the following equation:

$$
\begin{gathered}
\text { Percentage of Apoptotic Cells } \\
=\frac{\text { Total of Apoptotic cells }}{\text { Total of Apoptotic and Normal Cells }} * 100
\end{gathered}
$$

\section{Statistical analysis}

The significant level was ascertained by one way analysis of variance (ANOVA), followed by Tukey multiple comparison test. Results were presented as means $\pm \mathrm{SD}$ and $\mathrm{P}$ values of $<0.001$ were considered as significant.

\section{RESULTS AND DISCUSSION}

\section{MTT Assay}

According to the results of the MTT assay, brittle star methanol extract with concentrations of less than $20 \mu \mathrm{g} / \mathrm{ml}$ had no significant effect on cell viability, while the concentration of $150 \mu \mathrm{g} / \mathrm{ml}$ was associated with $50 \%$ apoptosis $(\mathrm{P}<0.001)$. In addition, higher concentrations of the extract were observed to cause complete apoptosis within the early hours (Fig. 1). 


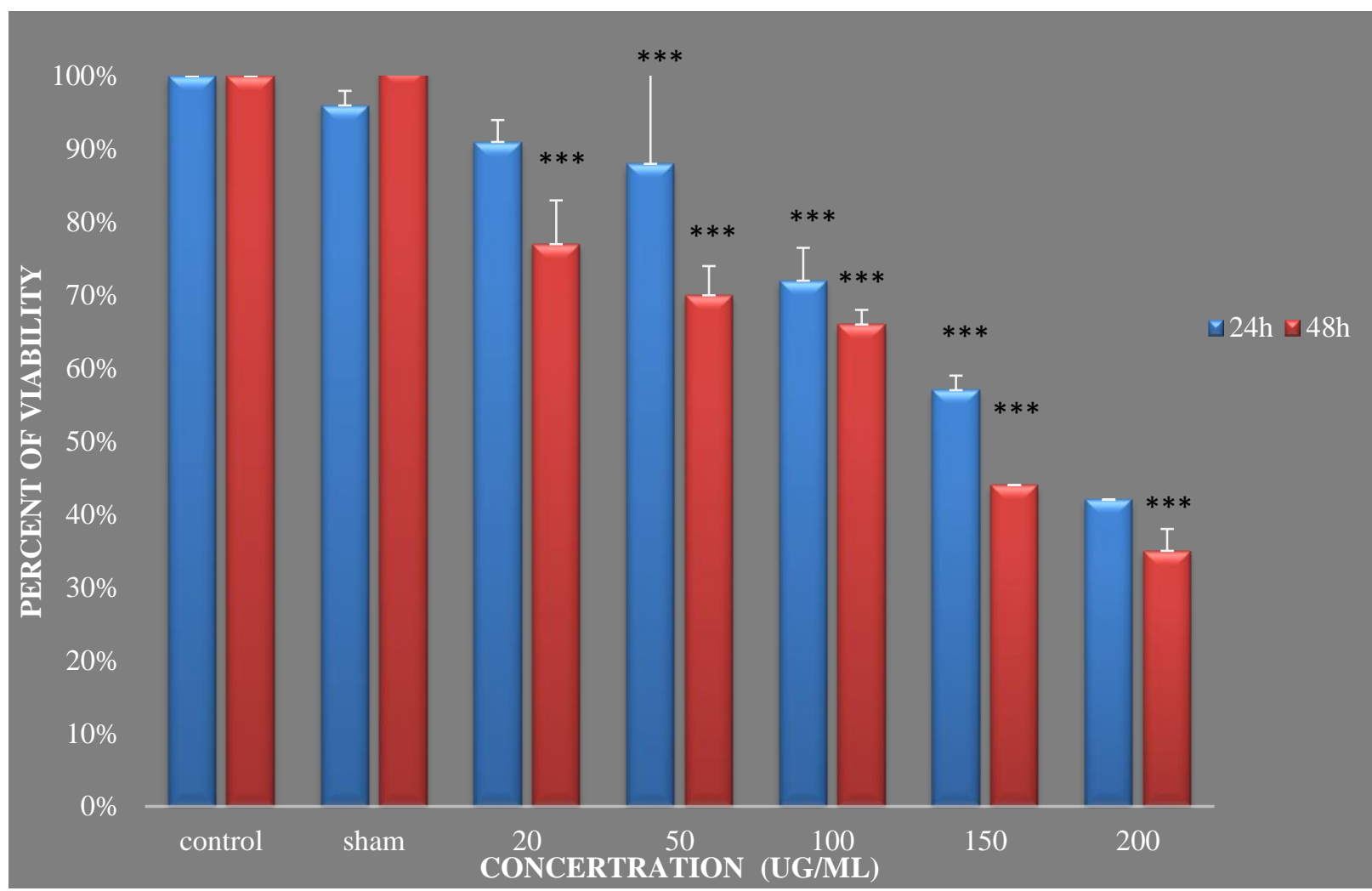

Fig. 1. Results of MTT Assay; brittle star extract decreased cell viability in a time- and dose-dependent manner.

\section{AO/EB Staining}

Acridine orange penetrates living cells and stains them green, while ethidium bromide penetrates dead cells and stains them red by connecting to their DNAs. In this method, apoptotic cells are stained orange, due to the infiltration of both acridine orange and ethidium bromide into the cells (Muranli, 2011).
Our findings showed that the cells treated by 150 $\mu \mathrm{g} / \mathrm{ml}$ of the brittle star methanol extract initiated apoptosis in $50 \%$ of the cells, while with the higher concentrations of the extract, the percentage of apoptotic cells increased, in comparison with the control groups (Fig. 2, Fig. 3).

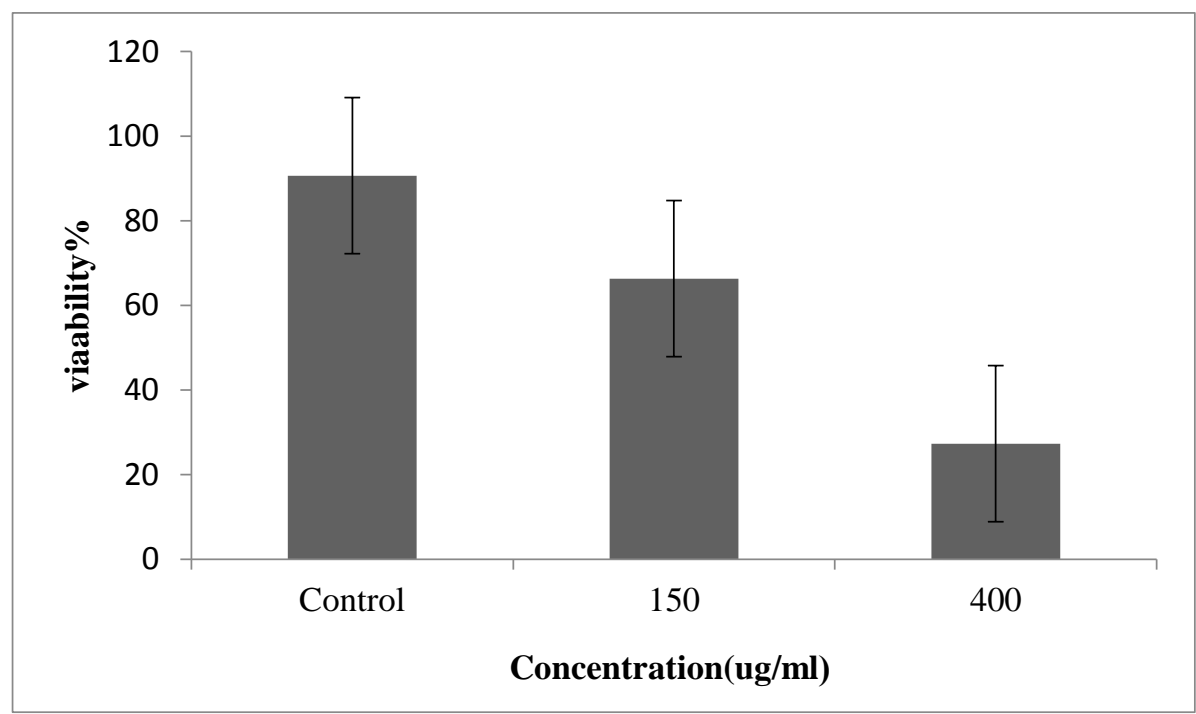

Fig. 2. Percentage of living cells marked by AO/EB staining $(\mathrm{P}<0.001)$. Sample images of AO/EB staining have also been presented below. 

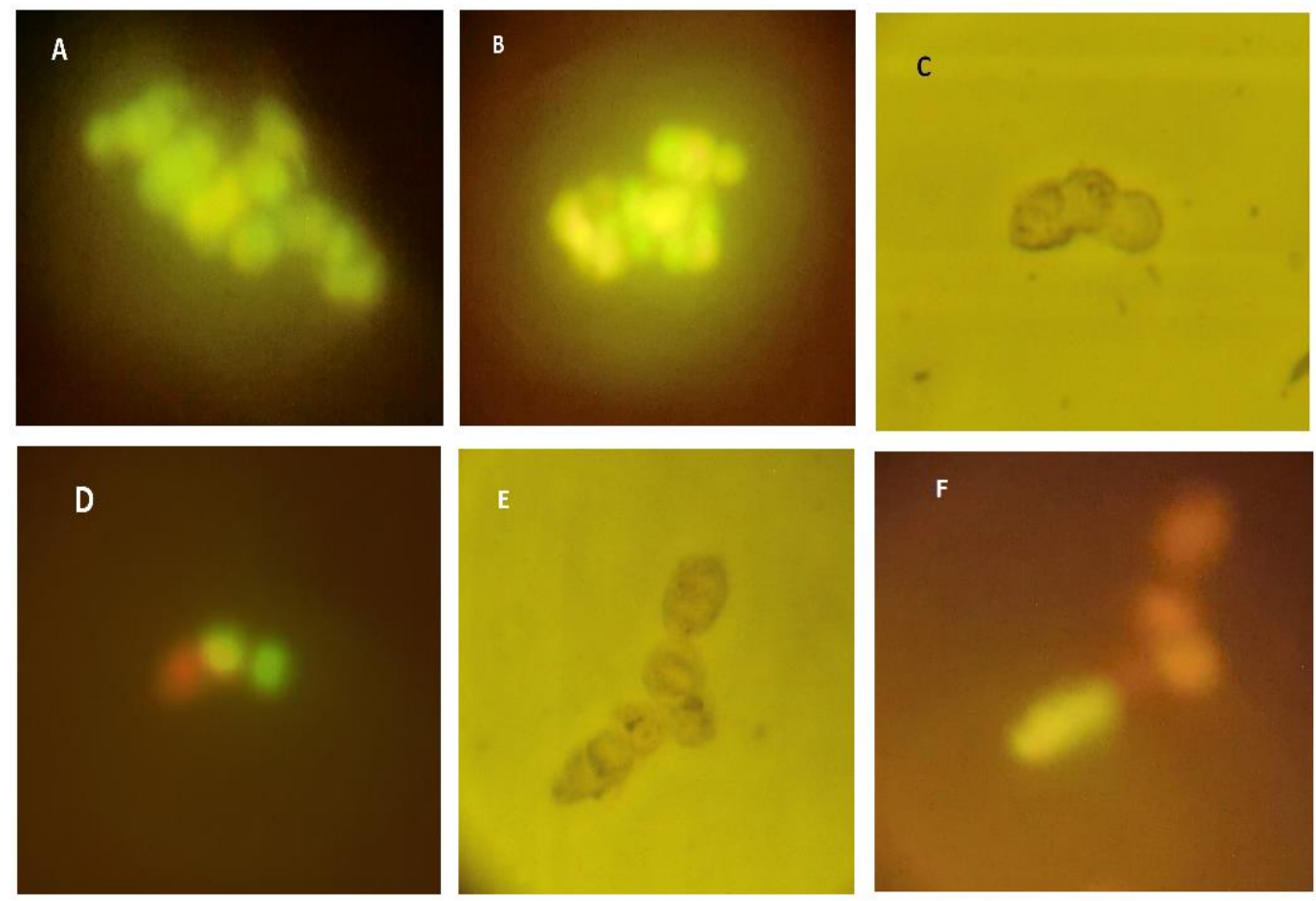

Fig. 3. Breast cancer cells (MCF-7); A-B) Control group; C) Treated by brittle star methanol extract with $150 \mu \mathrm{g} / \mathrm{ml}$ concentration (Normal Optical Microscope Image) D) Same image as $C$ observed by fluorescence microscopy; E) Treated by brittle star methanol extract with $400 \mu \mathrm{g} / \mathrm{ml}$ concentration (Normal Optical Microscope Image); F) Same image as $E$ observed by fluorescence microscopy (All images presented magnification 40X)

\section{Annexin V-PI}

In order to evaluate the type of the apoptosis induced by the brittle star methanol extract we used the Annexin- $\mathrm{V}$ and propidium iodide test. In this test, the apoptotic cells are marked by the Annexin- $\mathrm{V}$ fluorescent marker, while the cells with necrosis are marked by the propidium iodide stain.

In the present study the cells that were at an early apoptosis phase were distinguished by Annexin- $\mathrm{V}$ fluorescent, while they appeared negative for propidium iodide. On the other hand, the cells that were at a late apoptosis phase were positive for both Annexin- $\mathrm{V}$ fluorescent and propidium iodide. Moreover, necrotic cells appeared positive for propidium iodide and negative for Annexin- $\mathrm{V}$ fluorescent (Fig. 4).

As depicted in Fig. 4A, results of Annexin-V/PI indicated that in the untreated control group, there were $97.80 \%$ living cells, and apoptosis was observed in less than $2 \%$ of the cells.
Fig. 4B shows the cells treated by $150 \mu \mathrm{g} / \mathrm{ml}$ during six hours; accordingly, there were $77.69 \%$ of living cells, while $14.46 \%$ of the cells were in the early apoptosis phase, and $7.18 \%$ were in the late apoptosis phase. In addition, only $0.67 \%$ of the cells were observed to be necrotic. Fig. 4C depicts the cells treated by $150 \mu \mathrm{g} / \mathrm{ml}$ concentration of brittle star methanol extract for 24 hours, and as the results indicate, $54.36 \%$ of the cells were alive, $13.85 \%$ of the cells were in the early apoptosis phase, $29.02 \%$ were in the late apoptosis phase, and only $2.77 \%$ of the cells were affected by necrosis.

Flow cytometry results through Annexin-V/PI revealed that the Persian Gulf brittle star methanol extract could induce and contribute to apoptosis in a time-dependent manner. It is also noteworthy that the level of cell necrosis was significantly low in all the treatment durations. This could be regarded as an effectual strategy in cancer therapy. 

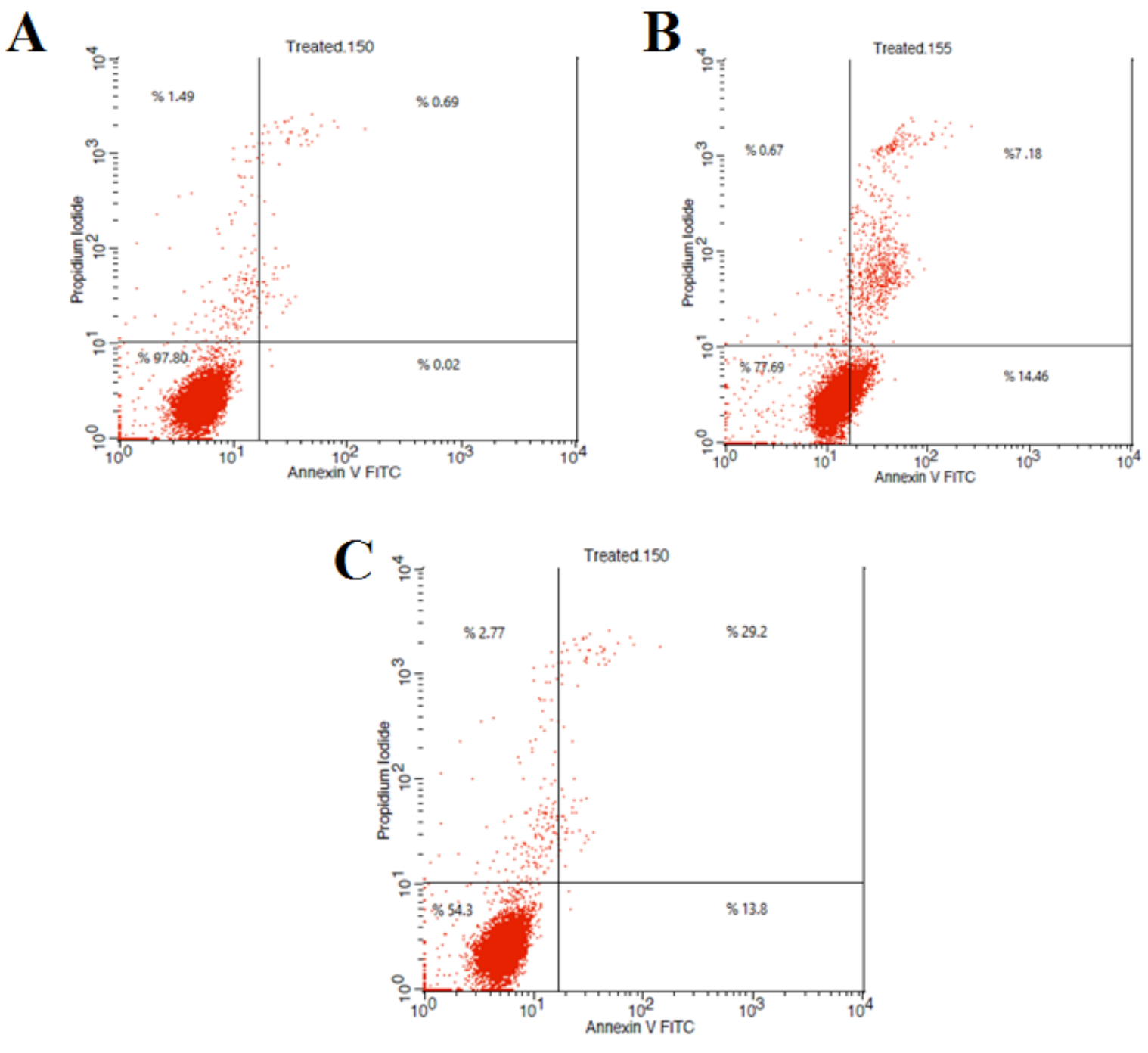

Fig. 4. Flow cytometry diagram; A) Control cells; B) Six-hour treated cells by brittle star methanol extract with $150 \mu \mathrm{g} / \mathrm{ml}$ concentration; C) 24-hours treated cells by brittle star methanol extract with $150 \mu \mathrm{g} / \mathrm{ml}$ concentration.

Nowadays, the use of natural compounds for the treatment of various diseases has attracted the attention of many researchers and healthcare professionals. Natural compounds are considered to be a new and important source of chemotherapy drugs such as vinblastine, vincristine and taxol (Gueritte, 2005). According to the literature these drugs have fewer side effects compared with their chemical counterparts. In addition, the production of these drugs is simpler.

It has been demonstrated that most of the marine medicinal products have anti-tumor, antiinflammatory and anti-infection properties. For instance, invertebrates and seaweeds are rich sources of active compounds which could be used for the into live cells and placed between two strains of DNA molecules (Mousavi et al., 2007); hence the live cells would appear green under fluorescent. On production of new agents. Other similar medicines include anti-tumor products (e.g., aplidine, didemnin $\mathrm{B}$ and bryostatin) that are extracted from invertebrates; cryptophycins that are extracted from green-blue algae; and anti-viral compounds (e.g., sulfated polysaccharides with the ability to control the immune system) that are extracted from red seaweeds.

Induction of apoptosis in cancer cells is one of the most crucial strategies in cancer therapy; therefore, we aimed to evaluate this phenomenon using predetermined methods. The initial procedures for the assessment of anti-cancer activities included the MTT assay, AO/EB staining and Annexin-V/PI kit. Acridine orange is an organic dye that can be move the other hand, ethidium bromide can enter dead cells, making them produce a fluorescent red color (Muranli, 2011). In the current research both acridine 
orange and ethidium bromide could enter the apoptotic cells, and an orange color was produced that was visible by a fluorescence microscope. In a study Aspergillus colonies that were in the apoptosis phase appeared orange, while the healthy colonies appeared green, and the dead colonies were red (Leles \& Factori, 2013).

In another research, Jitender Monga et al. (2013) investigated the apoptosis induction of cyanide L-3 in the MCF-7 cell line, reporting that this compound could affect apoptosis at certain concentrations. In addition, in the mentioned study, the cells that were in the apoptosis phase appeared orange, while the healthy cells were observed to become green, due to acridine orange infiltration, and the dead cells were stained red due to ethidium bromide infiltration (Monga et al., 2013).

According to the results of the present study brittle star methanol extract at the concentrations of less than $150 \mu \mathrm{g} / \mathrm{ml}$ caused no significant changes in the cells, while nearly $50 \%$ of the cells could enter apoptosis at this rate $(\mathrm{P}<0.001)$. Moreover, higher concentrations of brittle star methanol extract were associated with higher percentages of the cells undergoing cell death. Another sign in apoptotic cells during the primary phases is the loss of membrane symmetry and accumulation of ionic phosphatidylserine in the external layer of their lipid membrane (Rosenbaum et al., 2011). This phenomenon occurs actively through the internal transfer of aminophospholipid translocase (Mutee $e t$ al., 2012). Several proteins that connect to phosphatidylserine (e.g., protein S, Anxein and $2 \beta$ glycoprotein 1) can also connect to apoptotic cells as the binding molecules (Rosenbaum et al., 2011).

Immediately after apoptosis induction there is a rise in the level of cytoplasmic $\mathrm{Ca}^{2+}$, which leads to the elimination of the translocase function as well as the activation of the antiporters belonging to the scramblase family, ultimately releasing phosphatidylserine at the cell level (Zeng et al., 2013). In most cells phosphatidylserine is placed in the internal layer of the plasma membrane, which is the moderator of the membrane charge and accumulation of proteins in the membrane (Aubry et al., 1999). Presence of this phospholipid is the most important factor in directing the professional and non-professional phagocytes into their paths to reach the dead cells (Wang et al., 1998). Therefore, the interpretation of phosphatidyl serine and its connection to the binding molecules are essential to the investigations regarding apoptosis (Rosenbaum et al., 2011).

In the present study the results of the flow cytometry analysis by the Annexin-V/PI kit demonstrated that the Persian Gulf brittle star methanol extract could induce and contribute to apoptosis, depending on the duration of the treatment, so that $14.46 \%$ of the cells were at the primary phase of apoptosis six hours after the treatment, while in the control group this phase was observed in only $0.02 \%$ of the cells. Moreover, a declining trend was evident in the number of living cells in the control group in comparison with the sixhour and 24-hour treatment groups $(97.80 \%$ in the control group to $56.36 \%$ in the 24 -hour treatment group).

In a research conducted on K562 and KYM-1 cell lines and Jurkat cells by Jean-Pierre Aubry (1999), flow cytometry analysis revealed apoptosis induction in the cells, which is consistent with the results of the present study regarding the apoptotic effect of brittle star methanol extract on the MCF-7 cell line (Aubry et al., 1999). In another research by Szliszka (2011), the methanol extract of Brazilian beeswax was investigated and the flow cytometry analysis through Annexin-V/PI kit showed that this extract could induce apoptosis in the LNCaP prostate cancer cells (Szliszka et al., 2011). These findings are in congruence with the results of the current research.

Another study was performed on the NIH3T3 cell line to assess the trend in the plasma accumulation of phosphatidylserines by Rosenbaum (2011). According to the results, phosphatidylserine and Annexin- $\mathrm{V}$ were connected in the apoptotic cells, and this connection could be interpreted by flow cytometry (Rosenbaum et al., 2011). On the other hand, Foldbjerg (2010) used Annexin-V/PI analysis in order to investigate the effect of silver nanoparticles on the A549 cell line (human lung cancer cell line), reporting that silver nanoparticles exerted anti-cancer effects and induced apoptosis in this cell line (Foldbjerg et al., 2011), which is in line with the results of the present study.

\section{CONCLUSION}

According to the results of the present study, Persian Gulf brittle star methanol extract has antitumor properties and can control and induce cell 
death in the MCF-7 cell line at the concentrations around $150 \mu \mathrm{g} / \mathrm{ml}$. Based on the Annexin-V/PI kit analysis and $\mathrm{AO} / \mathrm{EB}$ staining, the type of this cell death is apoptosis.

\section{ACKNOWLEDGEMENT}

We hereby extend our gratitude to the respected associates of the Research Center for Animal Development and Applied Biology for assisting us in this research project.

\section{REFERENCES}

Amini, E., Nabiuni, M., Baharara, J., Parivar, K. and Asili, J. 2017. In vitro pro apoptotic effect of crude saponin from Ophiocoma erinaceus against cervical cancer. - Iran. J. Pharm. Res. 16: 264-276.

Aubry, J., Blaecke, A., Lecoanet-henchoz, S., Jeannin, P., Herbault, N. and Caron, G. 1999. Annexin V used for measuring apoptosis in the early events of cellular cytotoxicity. Cytometry 37: 197-204.

Carnevali, C. 2006. Regeneration in Echinoderms: repair, regrowth, cloning. - ISJ. 3: 64-76.

Entezar, M. 2012. Generalities of National Cancer Control Plans of Islamic Republic of Iran (First and Second Levels of Preventing Plans). - Arvij Iranian Publishing Co., Tehran.

Foldbjerg, R., Dang, D.A. and Autrup, H. 2011. Cytotoxicity and genotoxicity of silver nanoparticles in the human lung cancer cell line A549. - Arch. Toxicol. 85: 743-50.

Govindappa, M., Naga Sravya, S., Poojashri, M.N., Sadananda, T.S. and Chandrappa, C.P. 2011. Antimicrobial, antioxidant and in vitro antiinflammatory activity of ethanol extract and active phytochemical screening of Wedelia trilobata Hitchc. - J. Pharma. Phytother. 3: 43-51.

Gueritte, F. 2005. Anti-cancer Agents from Natural Products. Taylor and Francis Group: 123-136.

Leelaprakash, G. and Dass, S.M. 2011. In vitro antiinflammatory activity of methanol extract of Enicostemma axillare. - Int. J. Drug Dev. Res. 3: 189196.

Leles, S.M. and Factori, R.L. 2013. In situ analysis of apoptosis in Aspergillus nidulans with ethidium bromide and acridine orange. - Genetics Mol. Res. 12: 2895-901.

Monga, J., Pandit, S., Chauhan, C.S. and Sharma, M. 2013. Cytotoxicity and apoptosis induction in human breast adenocarcinoma MCF-7 cells by (+)-cyanidan3-ol. - Exp. Toxicol. Pathol. 65: 1091-1100.

Mousavi, SM., Montazeri, A., Mohagheghi, M.A., Jarrahi, AM., Harirchi, I. and Najafi, M. 2007.
Breast cancer in Iran: an epidemiological review. Breast J. 13: 383-391.

Muranli, F. 2011. Assessment of apoptosis by using ethidium bromide/acridine orange fluorescence staining method in lymphocyte cell cultures. - Curr. Opin. Biotechnol. 22: 1010-1016.

Mutee, A., Salhimi, S., Gazali, F., MutI, A.H., Li, C. and Ibrahim, K. 2012. Apoptosis induced in human breast cancer cell line by Acanthaster planci starfish extract compared to tamoxifen. - Afr. J. Pharm. Pharmacol. 6: 129-134.

Roohparvarzade, N., Ghaderi, M., Parsa, A. and Yari, A. 2014. The Emergence of Breast Cance Risk Factors in Women of 20 to 60 Age Range in Isfahan. - J. Iran Breast Dis. 7:52-61.

Rosenbaum, S., Kreft, S., Etich, J., Frie, C., Stermann, J. and Grskovic, I. 2011. Identification of novel binding partners (annexins) for the cell death signal phosphatidylserine and definition of their recognition motif. - J. Biol. Chem. 286: 5708-5716.

Saunders, F.R. and Wallace, H.M. 2010. On the natural chemoprevention of cancer. - Plant Physiol. Biochem. 48: 624-626.

Stoddart, M.J. 2011. Methods and Protocols in molecular Biology (Estimation of cell number Based on Metabolic Activity: The MTT Assay). 740.

Stoddart, M.J. 2011. Methods Protocols Mol. Biol 74.

Szliszka, E., Zydowicz, G., Janoszka, B., Dobosz, C., Kowalczyk-Ziomek, G. and Krol, W. 2011. Ethanolic extract of Brazilian green propolis sensitizes prostate cancer cells to TRAIL-induced apoptosis. Int. J. Oncol. 38: 941-953.

Wang, JM., Chertov, O. and Proost, P. 1998. Purification and identification of chemokines potenetially involved in kidney-specific metastasis by a murine lymphoma variant: induction of migration and NFkB activation. - Int. J. Cancer 75: 900-907.

Zeng, C., Ke, Z., Song, Y., Yao, Y., Hu, X. and Zhang, M. 2013. Annexin A3 is associated with a poor prognosis in breast cancer and participates in the modulation of apoptosis in vitro by affecting the Bcl2 / Bax balance. - Exp. Mol. Path. 95: 23-31.

$* * * * *$

How to cite this article:

Farrokhyar, S., Baharara, J. and Ramezani, T. 2018. Anti-cancer effects of the methanolic extract of Persian Gulf brittle star. - Nova Biol. Reperta 5 (3): 229-236. 